\title{
ANTITUMOUR EFFECT OF \\ A MIXTURE OF N-PROPYL POLYSULFIDES IN VITRO
}

\author{
Dragana Djordjevic ${ }^{1}$, Jelena Milovanovic ${ }^{2}$, Milena Jurisevic ${ }^{1}$, Bojana Stojanovic ${ }^{3}$, Olga Cvetkovic ${ }^{4}$, Marija Pergal ${ }^{4}$, Elizabeta Ristanovic, Danilo Vojvodic ${ }^{5}$, \\ Milos Simic ${ }^{6}$, Dragan Manojlovic ${ }^{7}$, Marija Milovanovic ${ }^{8}$ and Nebojsa Arsenijevic ${ }^{8}$ \\ ${ }^{1}$ University of Kragujevac, Faculty of Medical Sciences, Department of Pharmacy, Kragujevac, Serbia \\ ${ }^{2}$ University of Kragujevac, Faculty of Medical Sciences, Department of Histology, Kragujevac, Serbia \\ ${ }^{3}$ University of Kragujevac, Faculty of Medical Sciences, Department of Pathophysiology, Kragujevac, Serbia \\ ${ }^{4}$ Institute of Chemistry, Technology and Metallurgy, University of Belgrade, Belgrade, Serbia \\ ${ }^{5}$ Military Medical Academy, Faculty of Medicine, Belgrade, Serbia \\ ${ }^{6}$ Center for New Technologies, Belgrade, Serbia \\ ${ }^{7}$ University of Belgrade, Faculty of Chemistry, Belgrade, Serbia \\ ${ }^{8}$ University of Kragujevac, Faculty of Medical Sciences, Center for Molecular Medicine and Stem Cell Research, Kragujevac, Serbia
}

\begin{abstract}
ANTITUMORSIKI EFEITI SMEŠE N-PROPIL POLISULFIDA IN VITRO

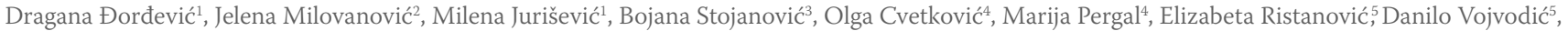
Miloš Simić, Dragan Manojlović 7 , Marija Milovanovićs i Nebojša Arsenijević ${ }^{8}$

${ }^{1}$ Univerzitet u Kragujevcu, Fakultet medicinskih nauka, Katedra za farmaciju, Kragujevac, Srbija

${ }^{2}$ Univerzitet u Kragujevcu, Fakultet medicinskih nauka, Katedra za histologiju, Kragujevac, Srbija

${ }^{3}$ Univerzitet u Kragujevcu, Fakultet medicinskih nauka, Katedra za patološku fiziologiju, Kragujevac, Srbija

${ }^{4}$ Univerzitet u Beogradu, Institut za hemiju, tehnologiju i metalurgiju, Beograd, Srbija

${ }^{5}$ Vojnomedicinska akademija, Medicinski fakultet, Beograd, Srbija

${ }^{6}$ Centar za nove tehnologije, Beograd, Srbija

${ }^{7}$ Univerzitet u Beogradu, Hemijski fakultet, Beograd, Srbija

${ }^{8}$ Univerzitet u Kragujevcu, Fakultet medicinskih nauka, Centar za molekulsku medicinu i istraživanje matičnih ćelija, Kragujevac, Srbija
\end{abstract}

Received / Primljen: 02. 12. 2017

Accepted / Prihvaćen: 13. 12. 2017.

\section{ABSTRACT}

Copper serves as a limiting factor for multiple steps of tumour progression, including angiogenesis, growth and metastasis. High levels of copper have been found in a wide spectrum of human cancers. Antitumour activities of copper-chelating drugs have been reported in animal models. Organosulfur compounds (diallyl sulfide, DAS; diallyl disulfide, DADS; S-ethylcysteine, SEC; $N$-acetylcysteine, NAC) derived from garlic exhibit marked copper-chelating activity. We analysed a mixture of fifteen n-propyl polysulfides (DPPS) for potential antitumour activity against several murine tumour cell lines, including colon carcinoma (CT26), mammary carcinoma (4T1) and melanoma cell lines (B16F10), and compared the effects with the antiproliferative effect in highly proliferative murine mesenchymal stem cells (mMSCs). The effects of the mixture of n-propyl polysulfides (100\%) on cell viability were determined using MTT assays. Cell apoptosis was analysed using Annexin V-FITC/PI assays.

The results of the MTT assays indicate that this standardized mixture of n-propyl polysulfides has a strong, dose-dependent cytotoxic effect against all three of the tested tumour cell lines (CT26, 4T1, B16F10). The cytotoxic effect of the n-propyl polysulfide mixture against the CT26 and B16F10 cell lines was much stronger than that of cisplatin and was significantly weaker in mMSCs, which are non-cancerous and highly proliferative cells, than in cancer cells. Flow cytometric analysis of CT26 and $4 T 1$ cells revealed that apoptosis was not the dominant mechanism of cell death induced by the n-propyl polysulfide mixture. The n-propyl polysulfide mixture exerted highly cytotoxic activity against murine colon carcinoma and melanoma cell lines, but its antiproliferative activity against mMSCs was significantly lower than that of cisplatin.

Keywords: n-propyl polysulfides, tumour cell lines, cytotoxicity, in vitro

\section{SAŽETAK}

Bakar učestvuje u različitim fazama progresije tumora, $u$ angiogenezi, rastu $i$ metastaziranju. Povećane vrednosti bakra u serumu i u tkivu tumora, karakteristika su različitih vrsta tumora kod ljudi. U animalnim eksperimentalnim modelima, supstance (lekovi) koje heliraju bakar ispoljavaju anti-tumorski efekat. Helatori bakra su i organosumporna jedinjenja, izolovana iz belog luka. U ovoj studiji analizirali smo potencijalnu anti-tumorsku aktivnost smeše petnaest različitih n-propil polisulfida na nekoliko mišjih ćelijskih linija tumora: karcinom kolona (CT26), karcinom dojke (4T1) $i$ melanom (B16F10). Aktivnost ove smeše na tumorskim linijama, uporedili smo sa antiproliferativnim efektom na mezenhimalne matične ćelije miša (engl. murine mesenchymal stem cells, mMSC). Efekat smeše n-propil polisulfida (100\%) na vijabilnost ćelija ispitali smo MTT testom. Apoptozu ćelija smo analizirali koristeći Annexin V-FITC/PI test.

Rezultati MTT testa ukazuju da standardizovana smeša n-propil polisulfida ima jak citotoksični, dozno-zavisni, efekat na sve tri testirane ćelijske linije tumora (CT26, 4T1, B16F10). Smeša n-propil polisulfida ispoljava izraženiji citotoksični efekat na CT26 i B16F10 linije u odnosu na cisplatinu. Citotoksični efekat ove smeše na mMSC je značajno slabiji poredeći sa efektom cisplatine, što ukazuje na selektivnije dejstvo. Analiza CT26 i 4T1 ćelija protočnom citometrijom pokazala je da apoptoza nije glavni oblik smrti ćelija, koju uzrokuje smeša n-propil polisulfda. Smeša n-propil polisulfida ispoljava jaču citotoksičnu aktivnost na ćelijskim linijama mišjeg karcinoma kolona $i$ melanoma i slabiju aktivnost na mMSC u poređenju sa efektom cisplatine.

Ključne reči: $n$ - propil polisulfidi, ćelijske linije tumora, citotoksičnost, in vitro

Corresponding author: Marija Milovanovic, MD, PhD Marija Milovanovic, MD, PhD
Center for Molecular Medicine and Stem Cell Research, Faculty of Medical Sciences, University of Kragujevac, Serbia Svetozara Markovica 69, 34000 Kragujevac, Serbia $\mathrm{Tel}+38134306800$, Fax. +38134306800112 E-mail: marijaposta@gmail.com 


\section{INTRODUCTION}

Copper is an essential trace element for most living organisms. It serves as a structural and catalytic cofactor for enzymes that play crucial roles in various biochemical processes (1). Copper is a cofactor in redox enzymatic reactions required for the normal growth and development of organisms. Since copper has roles in many enzymatic reactions $(1$, 2 ), its requirement in different aspects of cancer progression, such as immortalization, angiogenesis, and metastasis, is clear $(3,4)$. Copper can induce angiogenesis by directly binding to pro-angiogenic factors (such as VEGF) and by stimulating the migration of endothelial cells (5). It also triggers proliferative and metabolic enzymes that increase the ability of cancer cells to metastasize (3). Reduced or elevated levels of copper have been connected to various pathological conditions in humans. Many tumours tend to accumulate high concentrations of copper; the concentrations of copper in serum and tumour tissue are significantly higher in cancer patients than in healthy subjects, and the copper concentration correlates with cancer progression and therapeutic response $(6,7)$. High levels of copper have been found in a wide spectrum of human cancers, including breast, prostate, colon, lung, and brain cancer (6, 8-10). Furthermore, in comparison with normal tissues, tumours have a greater demand for copper and are more sensitive to reductions in systemic copper levels (11).

Antiangiogenic activities of copper-chelating drugs have been reported in animal models (11) (12). Another study reported impaired oxidative phosphorylation and tumour growth after pharmacological suppression of systemic copper, without concomitant effects on tumour angiogenesis (13). It has also been shown that copper chelation inhibits epithelial-to-mesenchymal transition and decreases the expression of vimentin and fibronectin, thus inhibiting the migratory and invasive properties of cells (14). Organosulfur compounds (diallyl sulfide, DAS; diallyl disulfide, DADS; S-ethylcysteine, SEC; N-acetylcysteine, NAC) derived from garlic exhibit marked copper-chelating activity (15).

Here, we analysed the potential antitumour activity of the mixture of fifteen n-propyl polysulfides against several murine tumour cell lines, including the colon carcinoma (CT26), mammary carcinoma (4T1) and melanoma cell lines (B16F10), and compared these effects with its antiproliferative activity against highly proliferative murine mesenchymal stem cells (mMSCs).

We show that the n-propyl polysulfide mixture exerts highly cytotoxic activity against murine colon carcinoma and melanoma cell lines, while its antiproliferative activity against mMSCs is significantly weaker than that of cisplatin.

\section{MATERIALS AND METHODS}

\section{Preparation of drug solutions}

The oil mixture of n-propyl polysulfides (100\%) and 10 $\mathrm{mM}$ cisplatin water solution were diluted in cell culture medium immediately before use. MTT, 3-(4,5-dimethylthiazol-2-yl)-2,5-diphenyl tetrazolium bromide, was dissolved $(5 \mathrm{mg} / \mathrm{mL})$ in phosphate-buffered saline with a $\mathrm{pH}$ of 7.2, and the solution was filtered through a $0.22 \mathrm{~mm}$ Millipore filter before use. All reagents were purchased from Sigma Chemicals.

\section{Cell culture}

CT26, 4T1, and B16F10 cells were purchased from American Type Culture Collection (ATCC, Manassas, USA). Mouse bone marrow-derived MSCs were purchased from Gibco. Cells were maintained in DMEM (Sigma Aldrich, Munich, Germany) supplemented with $10 \%$ foetal bovine serum (FBS, Sigma Aldrich, Munich, Germany), penicillin $(100 \mathrm{IU} / \mathrm{mL})$, and streptomycin $(100 \mu \mathrm{g} / \mathrm{mL})$ in a humidified atmosphere of $95 \%$ air and $5 \% \mathrm{CO} 2$ at $37^{\circ} \mathrm{C}$. Subconfluent monolayers in the $\log$ growth phase were harvested by a brief treatment with $0.25 \%$ trypsin and 0.02\% EDTA in phosphate-buffered saline (PBS, Sigma Aldrich, Munich, Germany), and the cells were washed three times in serum-free PBS. The number of viable cells was determined by trypan blue exclusion.

\section{Cytotoxicity assay}

The effects of the tested compounds on cell viability were determined using the MTT colorimetric technique. All examined cells were diluted with growth medium to $5 \times 10^{4}$ cells $/ \mathrm{ml}$, and aliquots $\left(5 \times 10^{3}\right.$ cells $\left./ 100 \mathrm{ml}\right)$ were placed in individual wells in 96 -well plates. The next day, the medium was exchanged with $100 \mu \mathrm{L}$ of test compound, which had been serially diluted 2 -fold in growth medium to concentrations ranging from $1 \mathrm{mg} / \mathrm{ml}$ to $0.008 \mathrm{mg} / \mathrm{ml}$. Both the n-propyl polysulfide mixture and cisplatin were tested in triplicate. Cells were incubated at $37^{\circ} \mathrm{C}$ and $5 \%$ $\mathrm{CO}_{2}$ for $24 \mathrm{~h}$. After incubation, the supernatant was removed, and $15 \%$ MTT solution $(5 \mathrm{mg} / \mathrm{mL}$ in PBS, $10 \mu \mathrm{L}$ ) in DMEM without FBS was added to each well. After an additional $4 \mathrm{~h}$ of incubation at $37^{\circ} \mathrm{C}$ in $5 \% \mathrm{CO}_{2}$, the medium with MTT was removed, and DMSO $(150 \mu \mathrm{L})$ with glycine buffer $(20 \mu \mathrm{L})$ was added to dissolve the crystals. The optical density of each well was determined at $595 \mathrm{~nm}$ using a Zenyth 3100 Multimode microplate detector. The percentage cytotoxicity was calculated using the formula: $\%$ cytotoxicity $=100-((E-B) /(S-B) * 100)$, where $B$ is the background optical density of medium alone, $S$ is the total viability/spontaneous death of untreated target cells, and $\mathrm{E}$ is the experimental well. Each of the tested complexes was evaluated for cytotoxicity in three separate experiments.

\section{Apoptosis assay}

For the detection of apoptosis, CT26 and 4T1 cells were plated in T25 culture flasks and allowed to grow overnight. After the cells reached subconfluency, the medium was replaced with the test substances $(0.01 \mathrm{mg} / \mathrm{ml})$. Treated cells were placed at $37^{\circ} \mathrm{C}$ in a $5 \% \mathrm{CO}_{2}$ incubator for 


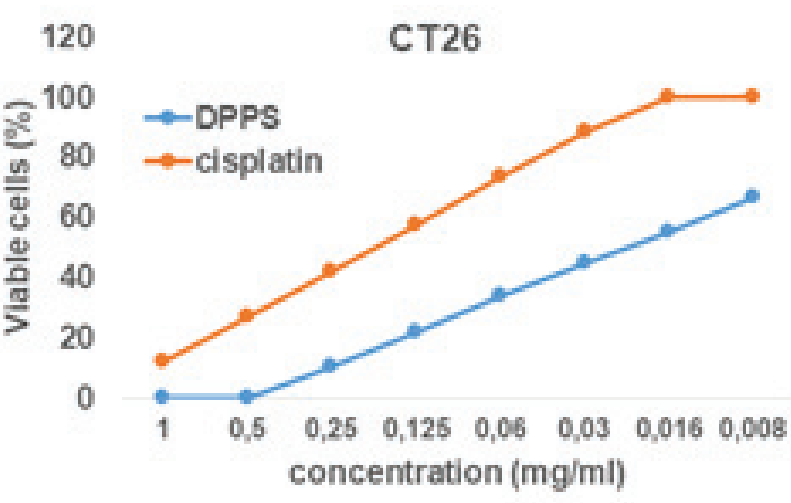

100

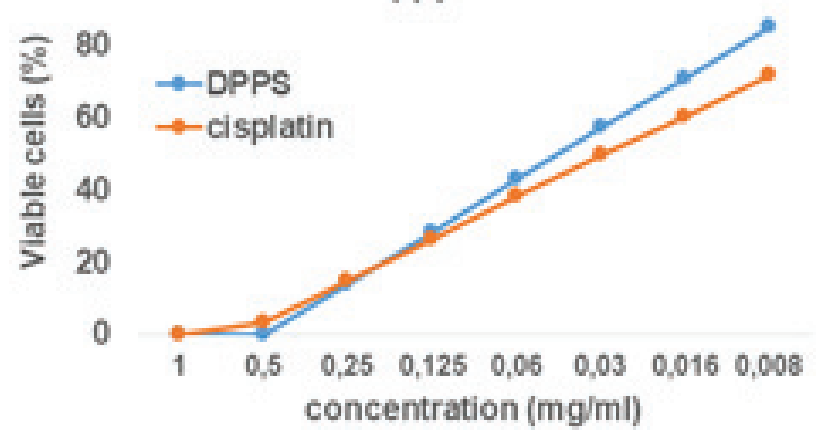

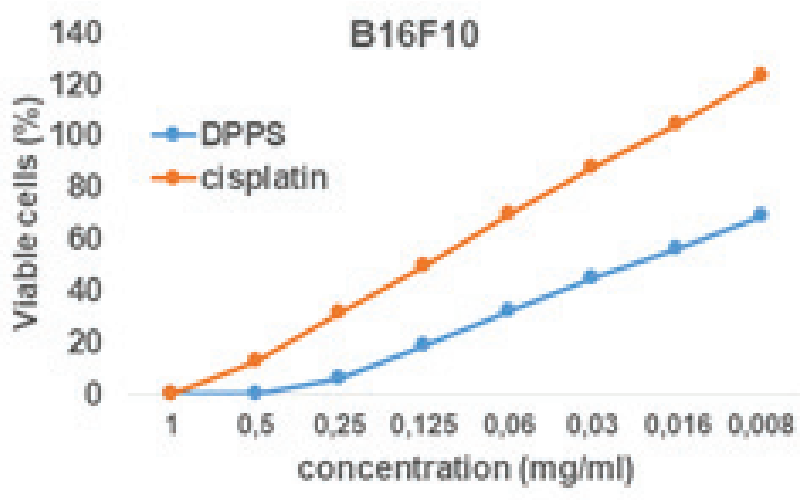

100

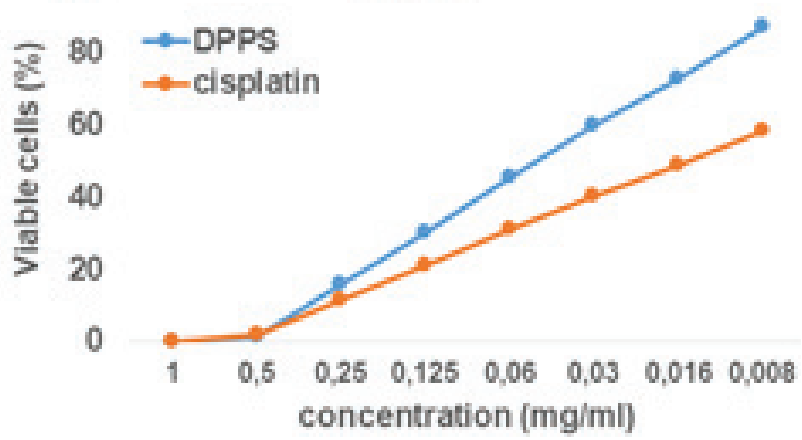

Figure 1. Graphs presenting the survival of CT26, B16F10, and 4T1 cells, as well as MSCs, after 24 h of growth in the presence of DPPS and cisplatin. Data are presented as the mean of three independent experiments.

$24 \mathrm{~h}$. The cultured cells were washed twice with PBS and resuspended in $1 \mathrm{X}$ binding buffer (10X binding buffer: 0.1 $\mathrm{M}$ Hepes/NaOH (pH 7.4), 1.4 M NaCl, $25 \mathrm{mM} \mathrm{CaCl} 2$ ) at a concentration $1 \times 10^{6} / \mathrm{mL}$. Annexin FITC and propidium iodide (PI) were added to $100 \mathrm{~mL}$ of cell suspension, which was then incubated for $15 \mathrm{~min}$ at room temperature $\left(25^{\circ} \mathrm{C}\right)$ in the dark. After incubation, $400 \mathrm{~mL}$ of $1 \mathrm{X}$ binding buffer was added to each tube, and the stained cells were analysed within $1 \mathrm{~h}$ using a FACS Calibur (BD, San Jose, USA) and Flow Jo software (Tri Star). Since Annexin V FITC staining precedes the loss of membrane integrity that accompanies the later stage identified by PI, an Annexin FITC-positive, PI-negative staining pattern indicates early apoptosis, while viable cells are Annexin V FITC negative and PI negative. Cells that are in late apoptosis or are already dead are positive for both Annexin V FITC and PI.

\section{RESULTS}

\section{Anticancer activity of copper complexes}

The results of the MTT assays indicate that the standardized mixture of n-propyl polysulfides has a strong, dose-dependent cytotoxic effect on all three of the tested carcinoma cell lines (CT26, 4T1, B16F10) (Figure 1). The n-propyl polysulfide mixture had almost the same cytotoxic activity as cisplatin against the 4T1 murine mammary carcinoma cell line. Interestingly, the cytotoxic effects of the n-propyl polysulfide mixture against the murine colon cancer and melanoma cell lines (CT26 and B16F10, respectively) were much stronger than those of cisplatin (Figure 1 ). Significant cytotoxic effects of the n-propyl polysulfide mixture against CT26 and B16 F10 cells were detected at even the lowest tested concentration $(0.008 \mathrm{mg} / \mathrm{ml})$. Importantly, compared with cisplatin, the tested mixture had significantly lower cytotoxicity against mMSCs, which are non-cancerous and highly proliferative cells (Figure 1). The similar effects of the tested mixture and cisplatin on $4 \mathrm{~T} 1$ cells and the significantly greater effects of the mixture against CT26 and B16F10 cells, as well as the lower cytotoxicity against mMSCs, were confirmed by analysis of the IC50 values (Table 1 ).

To determine the possible mode of death of the cells treated with the n-propyl polysulfide mixture, flow cytometry analysis of CT26 and 4T1 cells stained with Annexin $\mathrm{V}$ and PI after exposure to the test mixture (at a

Table 1. IC50 values (in mM) for 4T1, CT26, and B16F10 cells, as well as mMSCs, after exposure to DPPS and cisplatin for $24 \mathrm{~h}$ as determined by MTT assays. The data are presented as the mean \pm SD (standard deviation) from three experiments.

\begin{tabular}{|l|c|c|c|c|}
\hline \multicolumn{5}{|c|}{ IC50 $(\mathbf{m g} / \mathbf{m l})$} \\
\hline $\begin{array}{l}\text { Com- } \\
\text { pound }\end{array}$ & $4 \mathrm{~T} 1$ & CT26 & B16F10 & mMSC \\
\hline DPPS & $0.043 \pm 0.006$ & $0.024 \pm 0.018$ & $0.023 \pm 0.002$ & $0.059 \pm 0.002$ \\
\hline Cisplatin & $0.029 \pm 0.004$ & $0.160 \pm 0.092$ & $0.123 \pm 0.082$ & $0.028 \pm 0.006$ \\
\hline
\end{tabular}


untreated

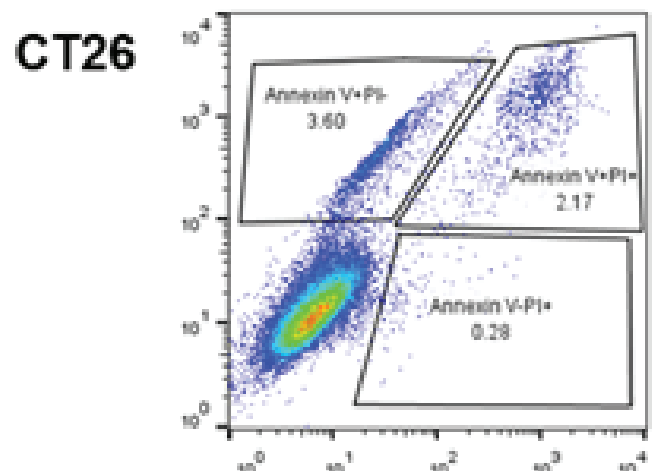

4T1 cisplatin
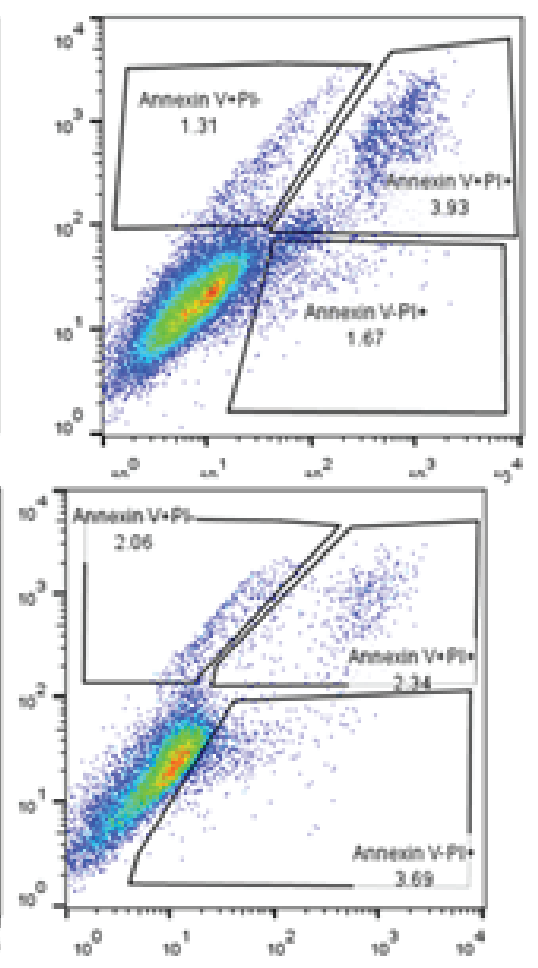

DPPS
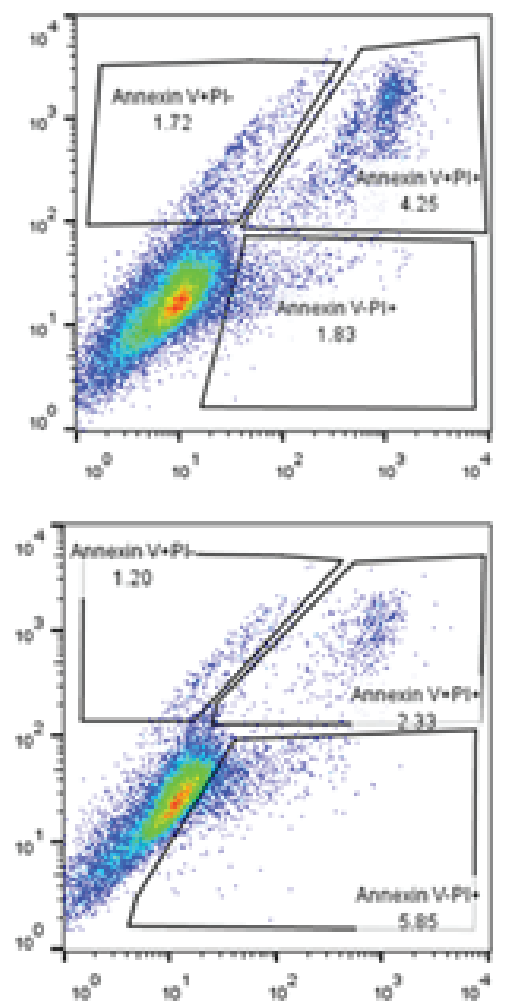

Figure 2. Representative flow plots showing the percentages of early- and late apoptotic and viable CT26 and $4 \mathrm{~T} 1 \mathrm{cells}$ after $24 \mathrm{~h}$ of treatment with DPPS $(0.01 \mathrm{mg} / \mathrm{ml})$.

concentration of $0.01 \mathrm{mg} / \mathrm{ml}$ ) for $24 \mathrm{~h}$ was performed. In agreement with the results of the MTT assays, a stronger cytotoxic effect of the n-propyl polysulfide mixture than of cisplatin, as determined by Annexin V PI staining, was observed in CT26 cells, while better cytotoxicity in 4T1 cells was shown for cisplatin (Figure 2). Furthermore, analysis of the percentages of stained CT26 and 4T1 cells after treatment with the test mixture and cisplatin indicated that apoptosis is not the dominant mechanism of cell death induced by the n-propyl polysulfide mixture. The percentage of $\mathrm{PI}+$ cells (Annexin $\mathrm{V}+\mathrm{PI}+$ and Annexin $\mathrm{V}-\mathrm{Pi}+$ ) was higher in the populations of both CT26 and $4 \mathrm{~T} 1$ cells treated with the test mixture than in those treated with cisplatin (Figure 2).

\section{DISCUSSION}

This study shows for the first time a greater cytotoxic effect of an n-propyl polysulfide mixture compared with a standard chemotherapeutic agent (cisplatin) in murine colon carcinoma (CT26), melanoma (B16F10), and mammary carcinoma (4T1) cell lines.

The biological activities of various organosulfur compounds are partially the result of their chelating activity (16). Metal cations, including $\mathrm{Cu}^{+}$and $\mathrm{Cu}^{2+}$, may be involved in the formation of chelating complexes (17). Four organosulfur compounds (diallyl sulfide (DAS), diallyl disulfide (DADS), S-ethylcysteine, and N-acetyl- cysteine) show marked copper-chelating capability. The method used to determine the chelating effects of DAS and DADS on copper is based on restoring the activity of xanthine oxidase, which is inhibited in the presence of copper (15).

Our finding that a mixture of n-propyl polysulfides, which may have chelating activities, reduces the viability of tumour cells agrees with previous findings. The copper chelating agent trientine supresses tumour development $(18,19)$. Curcumin, a polyphenol that belongs to the ginger family, chelates copper with high affinity and inhibits cell proliferation, invasion, metastasis, and angiogenesis (20). Administration of curcumin in animal tumour models resulted in the suppression of tumour growth associated with reduced copper concentrations in the serum of the treated groups (20). Furthermore, organic copper-binding compounds, such as clioquinol and pyrrolidine dithiocarbamate, bind copper and form new complexes that function as cancer-specific proteasome inhibitors and apoptosis inducers in human breast cancer cells (21).

More than $95 \%$ of the total copper in human plasma is associated with ceruloplasmin, while the remaining plasma copper is associated with albumin and transcuprein (22). It has been shown that the concentration of ceruloplasmin and transcuprein in tumour tissue is increased. Furthermore, tumour tissue can take up copper from the ceruloplasmin fraction of the plasma (22). Copper enters the cell through various transporter molecules in the plasma membrane, known as copper 
transporter protein 1 CTR1 (23), and binds to different factors, such as metallothionein, cytochrome oxidase, superoxide dismutase and the cytosolic copper chaperones Cox17 and Atox1 (24). Inhibitors of the copper trafficking proteins Atox 1 and CCS significantly reduce the proliferation of cancer cells with no effects on normal cells. Blocking copper trafficking induces cellular oxidative stress and reduces the cellular levels of ATP (25).

Our findings indicate that the reduction in the viability of murine MSCs (noncancerous and highly proliferative cells) in response to the n-propyl polysulfide mixture was smaller than that in response to cisplatin (Figure 1). This finding agrees with previous reports that copper chelating agents selectively kill human colon cancer cells without affecting the viability of noncancerous colon or intestinal cells (26). The selective cytotoxic activity of the n-propyl polysulfide mixture towards tumour cells may be the consequence of more pronounced chelating activity in tumour cells, as they contain higher amounts of copper. The higher percentage of necrotic tumour cells exposed to the n-propyl polysulfide mixture is in line with a previous finding that the organosulfur compound diallyl disulfide induces mainly necrotic death in Candida albicans (27).

Based on our findings, further studies should be done to explore the mechanisms of the antitumour action of this n-propyl polysulfide mixture, to elucidate the basis of the selective activity towards tumour cells and to evaluate for in vivo effects in animal tumour models.

\section{ACKNOWLEDGMENTS:}

This work was funded by grants from the Serbian Ministry of Science and Technological Development, Serbia (Grant Nos. ON175071, ON175069, and ON175103), and The Faculty of Medical Sciences, University of Kragujevac (MP 01/14, MP 02/14, and JP 24/10)

\section{REFERENCES:}

1. Grubman A, \& White AR. (2014). Copper as a key regulator of cell signalling pathways. Expert Rev Mol Med. 16:e11. doi: 10.1017/erm.2014.11.

2. Turski ML, \& Thiele DJ. (2009). New roles for copper metabolism in cell proliferation, signaling, and disease. J. Biol. Chem. 284:717-721.

3. Denoyer D, Masaldan S, La Fontaine S, \& Cater MA. (2015). Targeting copper in cancer therapy: 'Copper That Cancer'. Metallomics.7(11):1459-76.

4. Hanahan D, \& Weinberg RA. (2011). Hallmarks of cancer: The next generation. Cell. 144:646-674.

5. Gupte A, \& Mumper RJ. (2009). Elevated copper and oxidative stress in cancer cells as a target for cancer treatment. Cancer Treat Rev. 35(1):32-46.
6. Kuo HW, Chen SF, Wu CC, Chen DR, \& Lee JH. (2002). Serum and tissue trace elements in patients with breast cancer in Taiwan. Biol Trace Elem Res. 89(1):1-11.

7. Zuo XL, Chen JM, Zhou X, Li XZ, \& Mei GY. (2006). Levels of selenium, zinc, copper, and antioxidant enzyme activity in patients with leukemia. Biol Trace Elem Res. 114(1-3):41-53.

8. Nayak SB, Bhat VR, Upadhyay D, \& Udupa SL. (2003). Copper and ceruloplasmin status in serum of prostate and colon cancer patients. Indian J Physiol Pharmacol. 47(1):108-10.

9. Habib FK, Dembinski TC, \& Stitch SR. (1980). The zinc and copper content of blood leucocytes and plasma from patients with benign and malignant prostates. Clin Chim Acta. 104(3):329-35.

10. J.L., Díez M. Arroyo M. Cerdàn F.J. Muñoz M. Martin M.A. \& Balibrea J.L. (1989). Serum and Tissue Trace Metal Levels in Lung Cancer. Oncology; 46:230-234.

11. Brem S, Grossman SA, Carson KA, New P, Phuphanich S, Alavi JB, Mikkelsen T, \& Fisher JD. (2005). Phase 2 trial of copper depletion and penicillamine as antiangiogenesis therapy of glioblastoma. Neuro Oncol.7(3):246-53.

12. Yoshii J, Yoshiji H, Kuriyama S, Ikenaka Y, Noguchi R, Okuda H, Tsujinoue H, Nakatani T, Kishida H, Nakae D, Gomez DE, De Lorenzo MS, Tejera AM, \& Fukui H. (2001). The copper-chelating agent, trientine, suppresses tumor development and angiogenesis in the murine hepatocellular carcinoma cells. Int J Cancer. 94(6):768-773.

13. Ishida S, Andreux P, Poitry-Yamate C, Auwerx J, \& Hanahan D. (2013). Bioavailable copper modulates oxidative phosphorylation and growth of tumors. Proc Natl Acad Sci U S A.110(48):19507-12.

14. Shun Li, Jing Zhang, Hong Yang, Chunhui Wu, Xitong Dang, \& Yiyao Liua. (2015). Copper depletion inhibits $\mathrm{CoCl} 2$-induced aggressive phenotype of MCF-7 cells via downregulation of HIF-1 and inhibition of Snail/ Twist-mediated epithelial-mesenchymal transition. Sci Rep. 5: 12410.

15. Ou CC, Tsao SM, Lin MC, \& Yin MC. (2003). Protective action on human LDL against oxidation and glycation by four organosulfur compounds derived from garlic. Lipids. 38(3):219-24.

16. Campos JF, de Castro DT, Damião MJ, Vieira Torquato HF, Paredes-Gamero EJ, Carollo CA, Estevinho LM, de Picoli Souza K, \& Dos Santos EL. (2016). The Chemical Profile of Senna velutina Leaves and Their Antioxidant and Cytotoxic Effects. Oxid Med Cell Longev. 2016:8405957.

17. Flora SJ, \& Pachauri V. (2010). Chelation in metal intoxication. Int $\mathrm{J}$ Environ Res Public Health. $7(7): 2745-88$.

18. Yoshii J, Yoshiji H, Kuriyama S, Ikenaka Y, Noguchi R, Okuda H, Tsujinoue H, Nakatani T, Kishida H, Nakae D, Gomez DE, De Lorenzo MS, Tejera AM, \& Fukui H. (2001). The copper-chelating agent, trientine, sup- 
presses tumor development and angiogenesis in the murine hepatocellular carcinoma cells. Int J Cancer. 15;94(6):768-73.

19. Yoshiji H1, Yoshii J, Kuriyama S, Ikenaka Y, Noguchi R, Yanase K, Namisaki T, Kitade M, Yamazaki M, \& Fukui H. (2005). Combination of copper-chelating agent, trientine, and methotrexate attenuates colorectal carcinoma development and angiogenesis in mice. Oncol Rep. 14(1):213-8.

20. Zhang W, Chen C, Shi H, Yang M, Liu Y, Ji P, Chen H, Tan RX, \& Li E. (2016). Curcumin is a biologically active copper chelator with antitumor activity. Phytomedicine. 15;23(1):1-8.

21. Kenyon G Daniel, Di Chen, Shirley Orlu, Qiuzhi Cindy Cui, Fred R Miller, \& Q Ping Dou. (2005).Clioquinol and pyrrolidine dithiocarbamate complex with copper to form proteasome inhibitors and apoptosis inducers in human breast cancer cells. Breast Cancer Res. 7(6): R897-R908.

22. Hellman NE, \& Gitlin JD. (2002). Ceruloplasmin metabolism and function. Annu Rev Nutr. 22:439-58.
23. Ohrvik H, \& Thiele DJ. (2014).How copper traverses cellular membranes through the mammalian copper transporter 1, Ctr1. Ann N Y Acad Sci. 1314:32-41.

24. AC. Rosenzweig. (2001). Copper delivery by metallochaperone proteins. Acc Chem Res.34(2):119-28.

25. Wang J, Luo C, Shan C, You Q, Lu J, Elf S, Zhou Y, Wen Y, Vinkenborg JL, Fan J, Kang H, Lin R, Han D, Xie Y, Karpus J, Chen S, Ouyang S, Luan C, Zhang N, Ding H, Merkx M, Liu H, Chen J, Jiang H, \& He C. (2015). Inhibition of human copper trafficking by a small molecule significantly attenuates cancer cell proliferation. Nat Chem. 7(12):968-79.

26. Fatfat M, Merhi RA, Rahal O, Stoyanovsky DA, Zaki A, Haidar H, Kagan VE, Gali-Muhtasib H1, \& Machaca K. (2014). Copper chelation selectively kills colon cancer cells through redox cycling and generation of reactive oxygen species. BMC Cancer. 21;14:527.

27. Lemar KM, Aon MA, Cortassa S, O’Rourke B, Müller CT, Lloyd D. (2007). Diallyl disulphide depletes glutathione in Candida albicans. Yeast. 24(8):695-706. 